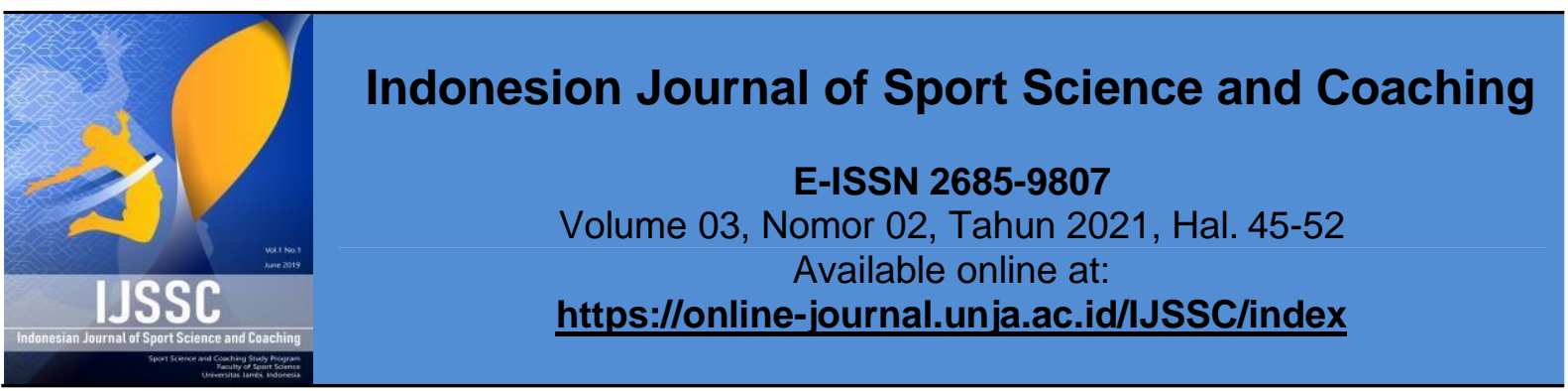

Research Article

OPEN ACCESS

\title{
Pengaruh Latihan Passing Bawah ke Dinding dan Berpasangan Terhadap Keterampilan Bola Voli pada Siswa Ekstrakurikuler di SMP Negeri 13 Tanjung Jabung Timur
}

\section{Effect of Down to Wall Passing Exercises and Pairs On Volleyball Skills on Extracurricular Students at State Junior High School 13 Tanjung Jabung Timur}

\author{
AHMAD SETIA BUDI \\ Program studi kepelatihan olahraga, FKIP, Universitas Jambi, Indonesia ${ }^{1}$
}

Correspondence Author: ahmad18@gmail.com

\begin{tabular}{|c|c|}
\hline Informasi Artikel & ABSTRACT \\
\hline Submit: $26-10-2021$ & $\begin{array}{l}\text { The basic skill of playing bolavoli is a ability to perform something basic } \\
\text { techniques of the game of football effectively and efficiently determined by } \\
\text { the speed, accuracy, shape, and ability to adjust. The method used in this } \\
\text { study is quantitative experiment, which is a study where researchers give } \\
\text { treatment after taking the initial test and will be taken again the final test } \\
\text { after being given treatment will then be seen whether the free variable plays } \\
\text { a role in the onset of a symptom, the sample in this study amounted to } 12 \\
\text { people. The training was conducted during } 16 \text { meetings. The conclusion of } \\
\text { this thesis is that the statistical test is calculated larger than the table or } \\
\text { (12.5) > (1.79588), so there is an influence of passing exercises under the } \\
\text { wall and pairing on the skills of passing under volleyball in extracurricular } \\
\text { students at State Junior High School } 13 \text { Tanjung Jabung Timur. } \\
\text { Keywords: Passing Down to the Wall, In Pairs }\end{array}$ \\
\hline Penerbit & ABSTRAK \\
\hline $\begin{array}{l}\text { Jurusan Pendidikan } \\
\text { Olahraga dan } \\
\text { Kepelatihan FKIP } \\
\text { Universitas Jambi } \\
\text { Jambi- Indonesia }\end{array}$ & $\begin{array}{l}\text { Keterampilan dasar bermain bolavoli adalah sebuah drajat kemampuan } \\
\text { untuk melakukan sesuatu teknik dasar permainan bolavoli secara efektif dan } \\
\text { efesien yang ditentukan oleh adanya kecepatan, ketepatan, bentuk, dan } \\
\text { kemampua dalam menyesuaikan diri..Metode yang digunakan dalam } \\
\text { penelitian ini yaitu kuantitatif eksperimen, yakni suatu penelitian dimana } \\
\text { peneliti memberikan perlakuan setelah diambil tes awal dan akan kembali } \\
\text { diambil tes akhir setelah diberi perlakuan kemudian akan terlihat apakah } \\
\text { variabel bebas berperan terhadap timbulnya suatu gejala, Sampel dalam } \\
\text { penilitian ini berjumlah } 12 \text { orang. Latihan yang diberikan dilakukukan selama } \\
16 \text { kali pertemuan.Kesimpulan dari skripsi ini adalah uji statistik t hitung } \\
\text { lebih besar dari pada t tabel atau (12.5) > (1.79588), jadi terdapat pengaruh } \\
\text { latihan passing bawah kedinding dan berpasangan terhadap keterampilan } \\
\text { passing bawah bola voli pada siswa ekstrakurikuler di SMP Negeri } 13 \\
\text { Tanjung Jabung Timur } \\
\text { Kata kunci: Passing Bawah ke Dinding. Berpasangan }\end{array}$ \\
\hline
\end{tabular}

This Indonesian Journal of Sport Science and Coaching is licensed under a CC BY-NC-SA (Creative Commons Attribution-ShareAlike 4.0 International License) 


\section{PENDAHULUAN}

Permainan bola voli dalam kehidupan masyarakat sangat popular dan diminati, hal ini dapat dibuktikan dengan banyaknya klub-klub bola voli diseluruh pelosok tanah air. Seiring perkembanganya, permainan bola voli dimainkan oleh seluruh kalangan, anak-anak sampai orang dewasa baik pria maupun wanita dan permainan bola voli ini sekarang dikenal tidak hanya sebagai olahraga prestasi, tetapi juga sebagai kegiata nuntu krekreasi. Olahraga mempunyai peran yang sangat penting dalam kehidupan. Dalam kehidupan modern saat ini manusia tidak dapat dipisahkan dari kegiatan olahraga, baik untuk meningkatkan prestasi maupun kebutuhan dalam menjaga kondisi tubuh agar tetap sehat. Dengan olahraga dapat membentuk manusia yang sehat jasmani dan rohani serta mempunyai watak disiplin dan akhirnya akan terbentuk manusia yang berkualitas.

Banyak jenis olahraga yang dapat dilakukan oleh masyarakat untuk menjaga kondisi tubuh dalam kondisi bugar. Berbagai jenis dapat dilakukan seperti jalan kaki, jogging, lari, basket, voli, badminton dan masih banyak lagi. Salah satu cabang olahraga yang digemari dikalangan masyarakat saat ini yaitu cabang olahraga bola voli, karena olahraga ini dapat dilakukan oleh semua kalangan, baiklaki-laki maupun perempuan. Olahraga bola voli merupakan salah satu cabang olahraga yang sudah berkembang di masyarakat luas, baik di klub-klub, kantorkantor, desa-desa, maupun sekolah-sekolah. Hal ini dikarenakan olahraga bola voli memerlukan peralatan yang sederhana serta mendatangkan kesenangan bagi yang bermain.

Bola voli merupakan cabang olahraga permainan beregu, maka antara pemain harus bekerja sama dan saling mendukung agar menjadi regu yang kompak dan tangguh. Dengan demikian penguasan teknik dasar permainan bola voli secara individual sangat diperlukan bagi seorang pemain bolavoli. Kesempurnaan dalam melaksanakan tehnik-tehnik dasar hanya dapat dikuasai dengan baik jika melakukan latihan yang teratur dan terprogram secara tepat. Metode-metode latihan yang tepat akan dapat mengurangi kesalahan-kesalahan yang dilakukan oleh seorang pemain. Dalam hal ini menguasai teknik dasar bola voli merupakan unsur yang sangat mendasar untuk mencapai prestasi bolavoli.

Berkaitan dengan teknik dasar bolavoli

M. Yunus (1992: 68) menyatakan bahwa, "Teknik dalam permainan bolavoli dapat diartikan sebagai cara memainkan bola dengan efektif dan efisien sesuai dengan peraturan permainan yang berlaku untuk mencapai hasil yang optimal". Menurut Soedarwo, Sunardi dan Agus Margono (2000: 6) bahwa, "Teknik dasar bolavoli adalah proses melahirkan keaktifan jasmani dan pembuktian praktek dengan sebaik mungkin untuk menyelesaikan tugas yang pasti dalam cabang olahraga permainan bolavoli".

Hal senada dikemukakan Dieter Beutelstahl (2003: 9) bahwa, "Teknik merupakan prosedur yang telah dikembangkan berdasarkan praktek, dan bertujuan mencari penyelesaian suatu problem pergerakan tertentu dengan cara yang paling ekonomis danberguna".

Berdasarkan tiga pendapat di atas dapat disimpulkan bahwa, teknik dasar permainan bolavoli merupakan suatu proses gerak tubuh yang dibuktikan dengan praktek yang dilakukan dengan sebaik mungkin dalam arti efektif dan efisien untuk menyelesaikan tugas yang pasti guna mencapai hasil yang baik dalam permainan bolavoli. Teknik permainan bolavoli merupakan aktivitas jasmani yang menyangkut cara memainkan bola dengan efektif dan efisien sesuai dengan peraturan permainan yang berlaku untuk mencapai suatu hasil yang maksimal. Teknik dasar yang sangat penting salah satunya yaitu passing bawah. Passing bawah merupakan salah satu teknik dasar bolavoli. Teknik ini digunakan untuk 
menerima servis, menerima spike, serta yang paling penting adalah untuk mengembalikan bola ke pengumpan atau tosser agar pengumpan dapat menciptakan serangan dengan mengumpan bola pada spiker untuk menjatuhkan bola di daerah lawan demi untuk mendapatkan angka.

Banyak bentuk-bentuk latihan passing bawah yang sering digunakan hanya pada saat pemanasan atau hanya pada awal latihan, tetapi yang banyak digunakan pada bentuk latihan passing bawah ke dinding dan pada bentuk latihan passing bawah berpasangan, dalam hal ini kedua bentuk latihan tersebut sering dipelajari pada para siswa baik saat pelajaran penjas maupun pada saat kegiatan ekstrakurikuler, tetapi bentuk latihan tadi terkadang hanya menjadi pemanasan tanpa diterapkan pada latihan teknik yang mengkhususkan mempelajari latihan passing bawah demi meningkatkan keterampilan passing bawah bola voli.

Teknik passing bawah biasanya jarang dipelajari secara khusus pada siswa Sekolah Menengah Pertama sekalipun itu pada waktu diluar jam pelajaran seperti pada saat ekstrakurikuler, passing bawah pada siswa sekolah menengah pertama hanya berlatih passing pada sela-sela pemanasan, para pelatih bolavoli di sekolah menengah pertama khususnya di SMP Negeri 13 Tanjung Jabung Timur jarang sekali menerapkan latihan passing bawah secara intensif, sehingga pada saat mengikuti pertandingan para siswayang bermain memiliki keterbatasan pada pertahanan dan juga bola pertama yaitu pada passing bawah, selain itu passing bawah merupakan hal dasar yang harus dimiliki pada setiap permainan, karena pada siswa SMP merupakan awal usia spesialisasi pada suatu cabang olahraga khususnya pada cabang olahraga bola voli. Karena itu teknik dasar passing bawah pada siswa di SMP Negeri 13 Tanjung Jabung Timur perlu dipelajari agar kemampuan individual khususnya pada kemampuan passing bawah dapat di tingkatkan. Selain itu peningkatan passing bawah dapat dilatih diluar jam pelajaran seperti pada ekstrakurikuler agar lebih banyak waktu latihan, oleh karena itu pada passing bawah perlu di pelajari secara khusus untuk meningkatkan kemampuan para siswa khususnya pada siswa yang mengikuti ekstrakurikuler di SMP Negeri 13 Tanjung Jabung Timur.

Berdasarkan pantauan peneliti di SMP Negeri 13 Tanjung abung Timur, olahraga bola voli yang diajarkan dalam mata pelajaran pendidikan jasmani olahraga dan kesehatan harus dikembangkan lagi pada kegiatan ekstrakurikuler agar siswa lebih menguasai teknik dalam bermain bolavoli. Salah satu teknik yang harus dikuasai adalah teknik passing bawah bola voli. Dalam hal ini penulis melihat siswa yang mengikuti ekstrakurikule rmasih kurang terampil dalam melakukan teknik passing bawah

Dengan demikian latihan passing bawah kedinding dan berpasangan diharapkan dapat meningkatkan keterampilan siswa dalam melakukan teknik passing bawah bola voli pada siswa ekstrakurikuler di SMPNegeri 13 Tanjung Jabung Timur.

Sebagai salah satu olahraga yang populer di Indonesia maupun di dunia bolavoli merupakan salah satu permainan bola besar dan paling sering dimainkan mulai dari anak- anak sampai dewasa diseluruh lapisan masyarakat. Permainan bolavoli seperti yang kita kenal saat ini merupakan bagian dari permainan dalam pertandingan duatimdan masing-masing tim berjumlah 6 pemain. Permainan bolavoli ini dimainkan di atas lapangan yang berbentuk persegi panjang dengan ukuran $18 \mathrm{~m} \times 9 \mathrm{~m}$ dan membagi dua lapangan permainan.

Menurut Del C.J. (2014:1013) mengatakan "bolavoli adalah olahraga tim yang kompleks dengan tehnik, taktik,dangerakan atletik tertentu. Pemain bolavoli melakukan perpindahan pendek, awalan yang diselingi dengan kecepatan dan lompatan dalam sikap bertahan atau menye-rang. Permainan ini dimainkan dengan lapangan yang dibagi oleh net dengan tinggi $2.43 \mathrm{~m}$ (untuk pria), ketinggian dalam 
melompat merupakan variabel yang paling penting untuk pemain bolavoli”. Tujuan utama permainan bolavoli ini untuk menjatuhkan bola secepat- cepatnya di daerah pertahanan lawan dengan melewati atas net tetapi sebelum itu pemain harus memiliki teknik dasar yang baik agar memudahkan dalam memainkan permainan bolavoli ini.

Hal senada di kemukakan oleh Roesdiyanto (1991:1) menyatakan bahwa ciri khas permainan bolavoli adalah "permainan beregu, dimainkan oleh dua regu yang masing-masing terdiri dari 6 orang disetiap lapangan dengan dipisahkan oleh net, pantulan yang dimainkan itu dengan tangan atau lengan". Dengan banyak berlatih maka seseorang dapat memiliki keterampilan dalam permainan bolavoli.

Menurut Winarno (2011:40) menyatakan bahwa permainan bolavoli merupakan cabang olahraga beregu yang dimainkan oleh enam orang pemain setiap regu, permainan ini akan berjalan dengan baik apabila setiap pemain minimal telah menguasai teknik dasar bermain bolavoli. Menurut Sanchez (2014:153) mengatakan "bolavoli adalah olahraga yang ditandai dengan gerakan- gerakan yang umum seperti melompat, pukulan lengan dan perpindahan yang pendek. Serangan dan memblokir sangat penting dalam permainan bolavoli untuk mencapai kemenangan dalam kompetisi tingkattinggi".

Berdasarkan pendapat ahli diatas, dapat ditarik kesimpulan bahwa permainan bolavoli adalah permainan yang terdiri atas dua regu yang beranggotakan enam pemain, dengan diawali memukul bola untuk dilewatkan diatas net agar mendapatkan angka, namun tiap regu dapat memainkan tiga sentuhan untuk mengembalikan bola. Permainan dilakukan diatas lapangan berbentuk persegi empat dengan ukuran $9 \mathrm{~m} \times 18 \mathrm{~m}$ dan dengan bentangan net ditengah-tengah lapangan.

Pembelajaran passing bawah merupakan suatu proses belajar yang dilakukan dengan cara bimbingan, pemberian pengetahuan atau materi passing dan pelatihan kepada pemain didalam suatu proses pembelajaran yang terprogram untuk mendapatkan hasil yang maksimal dalam pembelajaran teknik passing bawah dibutuhkan metode yangt epat, yaitu dengan metode passing bawah kedinding dan passing bawah berpasangan. Dengan adanya variasi yang diberikan sebelum evaluasi memungkinkan siswa dapat melakukan gerakan yang sempurna, pengontrolan dan perbaikan terhadap pola gerakan yang dilakukan akan mudah, yaitu pada waktu bermain atau sambil bermain.

Maka dengan demikiran penulis merancang pelaksanaan pembelajaran yang akan dibutuhkan sebagai pengamatan dalam mengetahui tingkat perkembangan dan keberhasilan dari pendekatan yang diterapkan yang mana pembukuan tersebut adalah perwujudan penulisan penelitian eksperimen. Penelitian lakukan dalam rangka meningkatkan keterampilan passing bawah bolavoli peserta ekstrakurikuler bolavoli di SMP Negeri 13 Tanjung Jabung Timur.

Jadi, dapat disimpulkan latihan passing bawah kedinding dan passing bawahberpasangan dalam bolavoli adalah bentuk latihan yang dapat dilakukan secara sistematis dan berurutan dengan menambah program kerjanya. Dari uraian diatas maka dapat dibuat skemasebagai berikut:

Latihan Passing Bawah Kedinding

- Latihan Passing Bawah Berpasangan
Keterampilan

Passing Bawah

Bola Voli

Gambar 1. Bagan kerangka Berfikir

\section{METODE}


Penelitian ini dilakukan di SMP Negeri 13 Tanjung Jabung Timur Jalan Sultan Hasanuddin Lambur II dari bulan November 2019 sampai dengan Januari 2020. Berdasarkan datanya penelitian ini termasuk penelitian kuantitatif. Menurut perlakuan pada sampel penelitian ini adalah penelitian eksperimen. Penelitian eksperimen adalah salah satu penelitian yang benar-benar dapat menguji hipotesis hubungan sebab akibat (Hamid Darmadi, 2011:175). Metode ini menyajikan pendekatan yang paling valid untuk menyelesaikan masalah-masalah yang ada dalam suatu penelitian.

Menurut Sutrisno Hadi (2000:260) metode eksperimen adalah kegiatan yang meliputi tes awal, pemberian latihan dan tes akhir dan tiap-tiap eksperimen pada akhirnya harus membandingkan sedikitnya dua kelompok atau lebih menjadi kegiatan utama dalam penyelidikan - penyelidikan ilmiah.

Menurut Jonathan Sarwono (2009:86) pre-test - post-test design merupakan design dengan cara melakukan satu kali pengukuran didepan (pre-test) sebelum adanya perlakuan (treatment) dan setelah itu dilakuakan pengukuran lagi (posttest). Dengan demikian hasil perlakuan dapat diketahui lebih akurat, karena dapat dibandingkan dengan keadaan sebelum diberi perlakuan.Untuk lebih jelasnya dapat digambarkan dengan rancangan sebagai berikut :

Tabel 1. Rancangan Penelitian

\begin{tabular}{ccc} 
Pretest & Treatmen & Posttest \\
\hline $\mathrm{Y} 1$ & $\mathrm{X} 1,2$ & $\mathrm{Y} 2$ \\
\hline
\end{tabular}

Keterangan:

Y1 : Pretest (tes awal) passing bawah kedinding dan berpasangan

$\mathrm{X} 1,2$ : Treatmen (perlakuan) passing bawah kedinding dan berpasangan

Y2 : Posttest (tes akhir) passing bawah kedinding dan berpasangan

Teknik pengumpulan data yang akan digunakan adalah dengan melakukan tes keterampilan passing bawah yang menjadi subjek dalam penelitian. Adapun mekanismenya adalah sebagai berikut:

a. Peserta berkumpul dilapanagan.

b. Peneliti memberi penjelasan serta arahan tentang tes yang akan dilakukan.

c. Selanjutnya peserta berbaris satu banjar kebelakang untuk menerima bola yang diberikan oleh petugas.

d. Petugas pelempar bola berdiri didepan para peserta.

e. Kemudian expert jugdement berdiri disamping kiri tengah diantara peserta dan petugas untuk melakukan penilaian.

f. Peserta melakukan passing bawah sebanyak 5 kali dengan bola dilempar oleh petugas secara bergantian.

g. Expert judgement mengamati dan menilai hasil passing bawah yang dilakukan oleh peserta menggunakan instrumen lembar penilaian tes keterampilan passing bawah bola voli.

h. Selanjutnya peneliti mengumpulkan hasil data penelitian keterampilan passing bawah bolavoli.

Setelah memperoleh data keterampilan passing bawah bolavoli peneliti mengambil kesimpulan dan saran berikut:

Untuk pengolahan data maka dibuat langkah-langkah perhitungan sebagai

1. Mencari rata-rata pada masing-masing variabel setiap data awal dan akhir, dengan mengunakan rumus:

$$
\begin{aligned}
& \mathrm{X}=\frac{\sum X}{n} \\
& \text { Keterangan : } \\
& \mathrm{X} \quad=\text { nilai rata-rata yang dicari }
\end{aligned}
$$




$$
\begin{array}{ll}
\sum \mathrm{x} & =\text { jumlah skor variabel } \\
\mathrm{N} & =\text { jumlah sampel }
\end{array}
$$

Mencari nilai (simpangan baku) dari masing-masing variabel pada test awa Idan test akhir, dengan menggunakan rumus variansi dan akar dari variansi dan akar dari variansi adalah nilai simpangan baku dengan rumus sebagai berikut:

Keterangan:

$$
S=n \sum x^{2}-\left(\sum \mathrm{x}\right)^{2}
$$

$\mathrm{S} \quad=$ variasi

$\mathrm{n} \quad=$ jumlah

$n \sum x^{2} \quad=$ jumlah dari nilai $\mathrm{X}$ kuadrat variabel $\mathrm{X}$ atau $\mathrm{Y}$

$\sum x \quad=$ jumlah dari variabel $\mathrm{X}$ dan $\mathrm{Y}$

HASIL DAN PEMBAHASAN

= jumlahdikurang 1 (derajatkebebasan)

Berdasarkan uraian yang telah dikumpulkan sebelumnya maka di dalam bab ini akan disajikan analisa pembahasan yang diperoleh dalam penelitian ini. Hasil penelitian ini akan digambarkan sesuai dengan tujuan dan hipotesis yang akan diajukan sebelumnya.

Hasil pengukuran tes keterampilan passing bawah, dapat dilihat dan terangkum pada tabel 2 sebagai berikut:

Tabel 2. Hasil Tes keterampilan passing bawah

\begin{tabular}{cccccc}
\hline Keterangan & Rata-rata & Sd & Varian & Jumlah nilai Maximum & Jumlah nilai Minimum \\
\hline Pretest & 9.25 & 2.34 & 5.48 & 14 & 7 \\
\hline Postest & 12.5 & 2.54 & 6.45 & 16 & 9 \\
\hline
\end{tabular}

Berdasarkan pengamatan penulis, pada saat proses pembelajaran siswa terlihat tidak bersemangat mengikuti pelajaran dikarenakan kurang adanya variasi program pembelajaran olahraga yang membangkitkan semangat, kemudian siswa tampak tidak memiliki keterampilan passing bawahyang baik sehingga siswa menjadi kurang bersemangat dalam menjalani aktivitas di lapangan dan siswa kerap kali mengeluh karena merasa bosan dengan metode program latihan yang selalu monoton. Hal ini mengindikasikan bahwa tingkat keterampilan passing bawahsiswa masih dalam kategori rendah, sehingga perlu ditingkatkan agar lebih baik lagi. Dengan tingkat keterampilan passing bawahyang baik diharapkan siswa tidak mudah merasakan lelah yang berlebih, sehingga ketika mengikuti proses program latihan yang umum pun juga tidak mudah lelah dan dapat terus berkonsentrasi.

Dalam pelaksanaan penelitian ini, peneliti memberikan perlakuan berupa latihan passing bawah kedinding dan berpasangan terhadap keterampilan passing bawah. Tetapi, sebelum memberikan perlakuan, peneliti memberikan tes keterampilan passing bawah. Dalam pelaksanaan penelitian ini, test dilakukan sebanyak dua kali yaitu tes awal dan tes akhir. Tes awal dilakukan bertujuan untuk melihat kemampuan awal sampel sebelum eksperimen dan tes akhir yang dilakukan bertujuan untuk melihat sejauh mana akibat eksperimen apakah terdapat peningkatan yang besrarti atau tidak. Cara mengetahui kemampuan sampel yaitu dengan pengamatan oleh orang yang berpengalaman dibidangnya dengan mencatat jumlah nilai tes keterampilan passing bawah.

Selanjutnya peneliti memberikan perlakuan passing bawah kedinding dan berpasangan. Penelitian dilakukan selama delapan belas kali pertemuan, dengan frekuensi pertemuan $3 \times$ dalam 1 minggu.

Dari proses perlakuan ini tampak hasil ketepatan keterampilan passing bawahtersebut dari rendah hingga pada saat tes akhir hasilnya lebih baik atau meningkat dari pada saat melakukan tes awal sebelum sampel diberikan perlakuan. Yang mana pada tahap awal latihan sebagian dari sampel tersebut masih belum 
maksimal saat melakukan tes keterampilan passing bawah, dengan adanya latihan passing bawah kedinding dan berpasangan terhadap keterampilan passing bawah, sedikit banyak dapat membantu dalam meningkatkan keterampilan passing bawah. $\mathrm{Hal}$ ini dikarenakan dengan latihan tersebut adanya latihan passing bawah kedinding dan berpasangan terhadapketerampilan passing bawah yang terprogram atau tersusun secara sistematis dapat membantu membiasakan sampel untuk melakukan gerakan yang ada pada saat melakukan tes keterampilan passing bawah dan dengan adanya latihan passing bawah kedinding dan berpasangan maka siswa dapat mengembangkan kekuatan otot lengan dari perlakuan latihan passing bawah kedinding dan berpasangan terhadap keterampilan passing bawah.

Dan setelah tahap perlakuan (Treatment) ini selanjutnya pada tahap terakhir yaitu tes akhir (Postest) prosedur pelaksanaan tes akhir ini dilakukan satu hari setelah selesai tahap perlakuan (Treatment) maka dilakukanlah tes akhir untuk mengukur hasil dari perlakuan (Treatment), disini akan terlihat hasil keterampilan passing bawahapakah terjadi peningkatan atau sebaliknya tidak sama sekali terjadi peningkatan. Dan hasil tes keterampilan passing bawahsesudah diberi perlakuan dapat terlihat jelas peningkatan hasil keterampilan passing bawah.

Berdasarkan hasil analisis dari tes awal sampai tes akhir diperoleh nilai $t_{\text {hitung }}$ sebesar 12.5 bila dibandingkan dengant tabel 1.79588. Ini menunjukkan terdapatnya pengaruh latihan passing bawah kedinding dan berpasangan yang berarti. Hal ini disebabkan oleh pelaksanaan latihan passing bawah kedinding dan berpasangan yang membuat siswa sering melakukan passing secara terus menerus dengan posisi yang benar sesuai yang diarahkan dan dipelajari, di mulai dari sikap tahap persiapan, tahap pelaksanaan, dan tahap lanjutan untuk melatih keterampilan passing bawah bla voli.

Hasil penelitian diketahui adanya pengaruh latihan passing bawah kedinding dan berpasangan terhadap keterampilan passing bawah. Latihan passing bawah kedinding dan berpasangan yang mengarah untuk melatih kemampuan siswa untuk melakukan pasing bawah yang baik

Dari analisis data yang dilakukan, yang dikemukakan dalam penelitian ini dapat diterima kebenarannya dengan menunjukan tes awal dan tes akhir berbeda, dengan kata lain terjadi peningkatan antara tes awal dan tes akhir, dan dapat disimpulkan bahwa terdapat pengaruh penelitian latihan passing bawah kedinding dan berpasangan terhadap keterampilan passing bawah bola voli pada siswa ekstrakurikuler di SMP Negeri 13 Tanjung JabungTimur.

\section{SIMPULAN}

Berdasarkan analisis data hasil penelitian dapat diketahui bahwa terdapat pengaruh latihan passing bawah kedinding dan berpasangan terhadap keterampilan passing bawah bola voli pada siswa ekstrakurikuler di SMP Negeri 13 Tanjung Jabung Timur. Kesimpulan penelitian yang dikemukakan didasarkan pada hasil-hasil uji-t (pada tabel lampiran 7) dalam pengujian hipotesis. Dikemukakan pula saran agar penelitian ini dimanfaatkan untuk meningkatkan keterampilan passing bawah atlet pada siswa ekstrakurikuler di SMP Negeri 13 Tanjung Jabung Timur.

\section{DAFTAR RUJUKAN}

Beutelstahl. D. (2015). Belajar Bermain Bola Volley. CV.PIONIR JAYA Bandung

Darmadi. H. (2011). Metode Penelitian Pendidikan. Alfabeta Bandung

Dasar, S., Ekawarna, E., Rahayu, F. D., \& Yuliawan, E. Upaya Meningkatkan Hasil Belajar Smash Bola Voli Siswa Kelas X SMK Negeri 5 Tanjab Barat Melalui Pendekatan Gaya Mengajar Latihan Power Tungkai Dengan Menggunakan Modifikasi Bola Gantung. JURNAL PRESTASI, 5(2), 44-51. 
Depdikbud (1993). Panduan Olahraga Bola Voli.Depdikbud Solo

Del C.J (2014) Bola voli.UPT. Penerbitan dan percetakan UNIS Jawa Tengah

Eko. P. (2012) Teknik Dasar Bermain Bolavoli. FIK UM Malang. Malang

Fajar. M.A (2003) Maajemen Ekstrakurikuler Dalam Mengembangkan Sekolah Berwawasan Lingkungan. Skripsi. Manajemen Pendidikan Islam UIN Maulana Malaik Ibrahim Malang

Faruq M.M. (2009). Berkarakter Dengan Olahraga, Berolahraga Dengan Berkarakter. PT. Java Pustaka Group. Surabaya

Hadisusanto. D. Dkk. (1995). Pengantar IImu Pendidikan. FIP UNY Yogyakarta

Hartanto. S.W. (2015). Pengaruh Latihan Passing Bawah Berpasangan Tetap dan Rotasi Terhadap Kemampuan Passing Bawah Pada Atlet Bola Voli Putri Klub Citra Serasi Kabupaten Semarang Tahun 2015. Skripsi. Universitas Negeri Semarang

Ma'mum. A. (1999). Pendekatan Keterampialan Taktis Dalam Permainan Bola Voli.Dirjen Olahraga. Jakarta

M. Yunus. (1991/1992). Olahraga Pilihan Bola Voli. Depdikbud

Prasetio. P.A. (2013). Keterampilan Gerakan Passing Bawah pada Bolavoli Melalaui Metode Tuturial Teman Sebeya Siswa Kelas VIII A SMP Negeri 4 Putri Hijau. Skripsi. FIK UNY Yogyakarta

Roesdiyanto. (1991/1992). Strategi dan Taktik Permainan Bola Voli. Malang: Departemen Pendidikan dan Kebudayaan IKIP Malang

Sanchez. (2014:315). Metode Penelitian Pendidikan Pendekatan Kuantitaif, Kualitatif, dan $R$ \& D.Alfabeta. Bandung

Sudiati. (2010). Tingkat Keterampilan Bermain Bolavoli Siswa Kelas V SDN Gambiran Kota Yogyakarta. Skripsi. FIK UNY Yogyakarta

Sugyono (2014:297). Prosedur Penelitian Suatu Teknik Pendekatan Praktik. PT. RINEKA CIPTA. Jakarta

Suharno. H.P. (1981). IImu Kepelatihan Olahraga. FPOK IKIP. Yogyakarta

Sunardi (2000). Permainan Besar II.Universitas Terbuka. Jakarta

Suprayogi A. (2011). Pengaruh Pembelajaran Model Bermain Terhadap Kemampuan Passing Siswa Peserta Ekstrakurikuler dalam Permainan Bolavoli di SMK Ganesa Satria 4 Kedu Temanggung. Skripsi. FIK UNY Yogyakarta

Nugraha, U., \& Yuliawan, E. (2021). Meningkatkan hasil belajar passing atas bola voli melalui pendekatan gaya mengajar latihan dengan menggunakan audio visual. Altius: Jurnal IImu Olahraga dan Kesehatan, 10(2), 231-242.

Winarno, M.E. (2006). Tes Keterampilan Olahraga.Laboratorium Jurusan IImu Keolahragaan FIP UM Malang. Malang

Yuliawan, E., \& Indrayana, B. (2020). Sosialisasi Pemahaman Penanganan Dan Pencegahan Sport Injury Pada Siswa SMP Muhammadiyah 1 Kota Jambi: Socialization of the Understanding of Handling and Prevention of Sport Injury to Students of SMP Muhammadiyah 1 Jambi City. Cerdas Sifa Pendidikan, 9(1), 56-63. 